Univerzitet u Beogradu
Poljoprivredni fakultet
Institut za poljoprivrednu tehniku
Naučni časopis
POLJOPRIVREDNA TEHNIKA
Godina XLV
Broj 1, 2020.
Strane: $88-98$

\title{
EVALUATION OF MAXIMUM BIOGAS PRODUCTION CAPACITY FROM DIFFERENT FEEDSTOCKS: AN EXPERIMENTAL STUDY
}

\author{
Ikechukwu Okosa $^{* 1}$, Onyenwoke Chukwuka Austine", \\ Horsfall Ibiba Taiwo ${ }^{1}$, Umunna Muofunanya Francis ${ }^{1}$. \\ ${ }^{1}$ Department of Agricultural and Bio-Resources Engineering, \\ Michael Okpara University of Agriculture, Umudike, \\ Abia State, Nigeria.
}

\begin{abstract}
This study reveals the maximum biogas production capacity of different biomass using plant and animal waste material as feedstock. A comparative experiment conducted under anaerobic condition showed that biogas yield from poultry litter (28 liters) was higher than that of rice husk (18 liters) in a 30day retention time. However, the yield of biogas was significantly influenced by the composition of the waste feedstock and the environmental conditions within the reactor. The poultry litter had already undergone some digestion process before it was excreted by the birds, which means their bonds were broken by digestive organisms which made the anaerobic digestion process to be easily accomplished. Similarly, the rice husk had a low gas production rate due to the presence of high lignin properties because rice is a lignin cellulose material. Therefore, for optimum gas production, the waste should be pretreated at lower temperate region to increase the digestion temperature since temperature exerts a major influence in biogas production.
\end{abstract}

Key words: prediction, maximum biogas capacity, poultry litter, rice husk, anaerobic digestion.

\footnotetext{
${ }^{1}$ Corresponding Author. E-mail.okosain@gmail.com
} 


\section{INTRODUCTION}

In Nigeria, energy is produced in low quantity and its consumption varies. As such there is need for an alternative source of energy to replace the fossil fuel energy source. However, the cost of energy (electricity, firewood and gasoline fuel) in Nigeria is of heavy charge, the bigger part corresponding to the cooking gas (Sioulas et al., 2008). The various challenges faced in reducing animal and plant wastes that causes environmental pollution and the various effects of using fossil fuel energy such as: (1) Non-Renewability:

As of today, fossil fuels are being extracted at an exorbitant rate to meet the gap between demand and supply and it is estimated that they will be finished in next 30-40 years Sioulas and Boukis, (2001). Since they are non-renewable, it is more likely that fuel expenses will face a steep hike in near future. It would take millions of years to replace coal, and oil, and this means that we will not be able to drive cars anymore unless we switch to electric cars that use energy from renewable energy sources or cars powered with biogas. This means once these non-renewable sources are completely used up, there is nothing more left (Petz, 2008). (2) Rising Prices of fossil fuel. Petroleum Exporting Countries (OPEC) which is a group of 13 countries including Nigeria, Iran, Iraq, Kuwait, Qatar, Saudi Arabia and UAE are responsible for 40 percent of the world's oil production and hold the majority of the world's oil reserves, according to the Energy Information Administration (EIA). OPEC constantly monitors the volume of oil consumed and then adjusts its own production to maintain its desired barrel price. This results in worldwide price fluctuations, according to the U.S. Department of Energy (Petz, 2008). (3) Effect on Human Health: Pollution related diseases range from mild to severe and can significantly affect quality of life. Air pollution can result in asthma, chronic obstructive pulmonary disorder and lung cancer. Long-term exposure may increase respiratory infections in general population (Petz, 2008).

Biogas production has long been a valuable technology, as the constant feed of organic raw materials such as energy crops, manure, and sewage sludge and plant residues help to produce energy. The ability to produce energy at a constant rate is a clear advantage over other renewable energy sources such as wind or solar energy, which depend on the wind or sun for production. The production and collection of biogas from a biological process was documented for the first time in United Kingdom in 1895. Since then, the process has been developed and broadly applied for wastewater treatment and sludge stabilization. The energy crisis in the early " 70 s brought new awareness about the use of renewable fuels, including biogas from anaerobic digestion. Nigeria as a nation with population of about 160 million people is blessed abundantly with different kinds of energy resources both renewable and non-renewable (Oyedebo, 2012). The interest in biogas has increased due to alternatives in fossil fuels used for energy production because of higher cost and the necessity of finding environmentally sustainable solutions for the treatment and recycling of animal manure and organic wastes. Biogas typically refers to a mixture of the different gases produced from the breakdown of organic matter in the absence of oxygen. Anaerobic digestion is a microbiological process of decomposition of organic matter, in the absence of oxygen, common to many natural environments and largely applied today to produce biogas in digesters (Kanokwan, 2006). 


\section{MATERIAL AND METHODS}

\section{Description of study location}

The study was conducted in the Engineering workshop of Michael Okpara University of agriculture, Umudike.

Umudike is a semi-urban settlement in Ikwuano LGA, Abia State, Nigeria, about 11 kilometers Southeast of Umuahia, the state capital city.

Umudike lies between latitude $5.4801^{\circ} \mathrm{N}$ and longitude $7.5437^{\circ} \mathrm{E}$ in the rain forest area of South-East agricultural zone of Nigeria and 152 meters elevation above the sea level. The state is located east of Imo state and shares common boundaries with Anambra, Enugu and Ebonyi states, to the North-West, North and North-East, respectively.

\section{Feedstock Procurement}

The animal waste being poultry litter was collected from the National Research Institute Umudike Poultry farm. The poultry waste used was free from wood shavings since they were obtained from battery cage farming. The rice husks were gotten from Bende local government rice mill. The type of digester that was used in the course of this research was a batch-type digester. This type of digester was chosen because it allows feedstock to be digested in batch levels. Batch digesters are mostly used for experimental purposes and for research study.

\section{Experimental design and Analysis}

The animal waste being poultry litter was collected from the National Research Institute Umudike Poultry farm. The poultry waste used was free from wood shavings since they were obtained from battery cage farming. The rice husk where gotten from Bende local government rice mill. The type of digester that was used in the course of this research was a batch-type digester. This type of digester was chosen because it allows feedstock to be digested in batch levels. Batch digesters are mostly used for experimental purposes and for research study.

\section{Experimental Procedure}

The substrate was carefully weighed was added with water in a ratio of $1: 1$ and was transferred to be fed into the digester through the inlet chamber. Before the introduction of this substrate to the digester, the substrate $\mathrm{pH}$ level was checked also with the ambient and slurry temperature. Rice husk and poultry litter were mix with water to the digester at a ratio of 1:1. The total volume of the substrate in addition to water mixture in the digester where at $80 \%$ leaving $20 \%$ gas volume where the gas will be retained. since the digester was a 30 liter digester, so $80 \%$ of 30 litter is 24 liter and at a ratio of 1:1 means that the wastes to water volume was $12 \mathrm{~kg}$ and 12 liters respectively according to substrate addition rate by Ojikutu and Osokoya, (2014). To achieve homogeneity of the slurry, it was continually stirred so that it will not form scum beneath the digester 
because once this happens it will slow down the rate of digestion and the microorganisms responsible for the breakdown of the substrate will only be active at a particular spot, Using the built-in stirrer, the slurry was stirred regularly to distribute and maintain uniformity of temperature and thus, the thickening and caking of scum was prevented. Stirring did not only distribute temperature, it also ensured even distribution of bacteria and at the same time improved surface contact of the waste with the anaerobic bacteria, thereby speeding up biochemical reaction of fermentation.

\section{Temperature Monitoring}

In this study, ambient and slurry temperatures were monitored on daily basis. The $\mathrm{pH}$ level of the slurry was monitored daily using a $\mathrm{pH}$ meter.

According to Adelekan and Bamgboye (2009) that $\mathrm{pH}$ is one of the major factors that affects biogas production and that the micro-organisms that are involved in anaerobic reaction required a neutral or mildly alkaline environment for optimum performance.

\section{Retention time}

The poultry waste and rice husk were subjected to a 14 (days) retention time, during which the waste was allowed to stay in the bio-digester and their gas production rates were taken at intervals.

\section{Pre-treatment process of feedstock}

Prior to digestion the feedstock was partially fermented by soaking in water for fifteen days to help in softening and breaking down of the lignin matter because rice husk is a lignin-cellulose material by mechanical pretreatment method of crushing to fine particles. Crushing prepares the surfaces of the particles for biological decomposition and the subsequent methane production. As a general rule, the decomposition process is faster when the particle size is smaller. The following instruments were used in the study: (1) a weighing balance was used for taking the weight of test samples. (2) plastic measuring cylinder was used for measuring the volume of gas produced. (3) mercury-inglass thermometer was used for monitoring the ambient and slurry temperatures. (4) a digital $\mathrm{pH}$ meter of range 0-14 was used for daily recording of test samples for their $\mathrm{pH}$ level.

\section{Moisture content determination}

The moisture content of the waste was determined by subjecting the feedstock to oven drying method. The crucibles to be used were washed and dried using an oven at $105^{\circ} \mathrm{c}$ for 30mins and then allowed to cool in desiccators. Pre-weighed samples were placed in the crucible and then inserted into the oven set at 105 degrees Celsius for 5hours.the samples were then removed from the oven after this period then cooled and weights were intermittently recorded until a uniform weight was achieved. 


\section{Determination of Total Solid, Organic dry matter content, Ash content}

The oven dried samples that were used in determining moisture content gave us the total solid that were present in the test sample. To determine the ash content, a little quantity of the pre-dried test sample was burnt in a muffle-furnace at $650^{\circ} \mathrm{C}$ for 6 hours according to Ojikutu and Osokoya (2014).

Percentage organic matter content $=\frac{\% \text { dry matter }- \text { ash content }}{\% \text { dry matter }}$

Percentage ash content $=\frac{\text { weight of crucible }+ \text { ash }- \text { crucible }}{\text { oven dry weight of sample }}$

\section{Determination of Percentage Volatile content and Fixed Carbon content}

The percentage volatile content and fixed carbon for the waste were calculated using a mathematical equation as the weight of biomass substrate from the weight remaining after digestion over weight of biomass expressed as a percentage according to Ehiem and Adama (2014). The performance evaluation for the waste was evaluated according to Adelekan and Bamgboye (2009).

Table 1. Moisture Content of Rice husk and Poultry litter.

\begin{tabular}{|l|c|c|c|c|}
\hline Waste Type & $\mathrm{W}_{\mathrm{S}}(\mathrm{kg})$ & $\mathrm{W}_{\mathrm{ds}}(\mathrm{kg})$ & \multicolumn{2}{|c|}{ Moisture content (\%) } \\
\hline Rice husk & 5.00 & 4.32 & $15.7^{d b}$ & $13.6^{\text {wb }}$ \\
\hline Poultry litters & 5.00 & 3.2 & 56.25 & 36.0 \\
\hline
\end{tabular}

wb - wet basis, db - dry basis

Table 2. Bioconversion Efficiency of Rice husk and Poultry litter.

\begin{tabular}{|l|c|c|c|}
\hline Waste Type & $W_{1}(\mathrm{~kg})$ & $W_{2}(\mathrm{~kg})$ & Conversion efficiency (\%) \\
\hline Rice husk & 24.00 & 21.10 & 12.08 \\
\hline Poultry litter & 24.00 & 19.30 & 19.58 \\
\hline
\end{tabular}

Table 3. Composition of substrates

\begin{tabular}{|l|c|c|}
\hline \multicolumn{1}{|c|}{ Parameters (\%) } & Rice husk & Poultry litter \\
\hline Moisture content & 15.7 & 56.25 \\
\hline Ash & 4.16 & 7.81 \\
\hline Total solid & 4.32 & 3.2 \\
\hline Fixed carbon & 76.89 & 61.94 \\
\hline Volatile solid & 3.25 & 4.0 \\
\hline
\end{tabular}


Table 4. Operating parameters for biogas production: poultry litter feedstock

\begin{tabular}{|c|c|c|c|c|}
\hline Time (days) & $\begin{array}{l}\text { Ambient Temp } \\
(\operatorname{deg} C)\end{array}$ & $\begin{array}{l}\text { Slurry Temp } \\
(\operatorname{deg} C)\end{array}$ & $p H$ & Gas vol. $(L)$ \\
\hline 1 & 36 & 39 & 6.4 & 0.0 \\
\hline 2 & 32 & 36.5 & 6.4 & 0.0 \\
\hline 3 & 30 & 33.75 & 6.0 & 1.38 \\
\hline 4 & 37 & 41.7 & 5.8 & 1.46 \\
\hline 5 & 32 & 40 & 5.5 & 1.4 \\
\hline 6 & 34 & 36 & 5.4 & 1.2 \\
\hline 7 & 32 & 33.5 & 5.4 & 0.98 \\
\hline 8 & 31 & 32 & 5.2 & 0.94 \\
\hline 9 & 30 & 30 & 5.2 & 1.2 \\
\hline 10 & 36 & 34 & 5.0 & 1.4 \\
\hline 11 & 32 & 30 & 5.1 & 1.2 \\
\hline 12 & 34 & 36 & 5.0 & 1.44 \\
\hline 13 & 31 & 32 & 5.2 & 1.2 \\
\hline 14 & 30 & 31 & 5.4 & 1.0 \\
\hline 15 & 29 & 28 & 5.2 & 0.53 \\
\hline 16 & 30 & 29 & 5.1 & 0.32 \\
\hline 17 & 28 & 28 & 5.1 & 0.62 \\
\hline 18 & 29 & 30 & 5.0 & 0.3 \\
\hline 19 & 29 & 31 & 5.1 & 0.58 \\
\hline 20 & 32 & 36 & 5.0 & 1.1 \\
\hline 21 & 33 & 32 & 5.1 & 1.27 \\
\hline 22 & 31 & 30 & 5.1 & 1.3 \\
\hline 23 & 34 & 33 & 5.2 & 1.32 \\
\hline 24 & 30 & 31 & 5.2 & 1.0 \\
\hline 25 & 31 & 33 & 5.2 & 0.98 \\
\hline 26 & 34 & 37 & 5.0 & 1.50 \\
\hline 27 & 31 & 33 & 5.2 & 0.34 \\
\hline 28 & 32 & 34 & 5.2 & 0.32 \\
\hline 29 & 31 & 30 & 5.1 & 1.3 \\
\hline 30 & 28 & 30 & 5.0 & 1.0795 \\
\hline
\end{tabular}

Table 5. Operating parameters for biogas production: rice husk feedstock

\begin{tabular}{|c|c|c|c|c|}
\hline $\begin{array}{c}\text { Time } \\
(\text { days })\end{array}$ & $\begin{array}{c}\text { Ambient Temp } \\
(\text { degC })\end{array}$ & $\begin{array}{c}\text { Slurry Temp } \\
(\text { degC })\end{array}$ & $p H$ & $\begin{array}{c}\text { Gas vol } \\
(\text { L })\end{array}$ \\
\hline 1 & 36 & 34 & 5.6 & 0.0 \\
\hline 2 & 32 & 36 & 5.6 & 0.0 \\
\hline 3 & 30 & 38 & 5.2 & 0.0 \\
\hline 4 & 37 & 36 & 5.0 & 0.0 \\
\hline 5 & 32 & 37 & 5.2 & 0.1 \\
\hline 6 & 34 & 34 & 5.0 & 0.2 \\
\hline 7 & 32 & 36 & 5.1 & 0.06 \\
\hline 8 & 31 & 29 & 4.9 & 0.11 \\
\hline 9 & 30 & 36 & 4.8 & 0.12 \\
\hline 10 & 36 & 36 & 4.9 & 0.2 \\
\hline 11 & 32 & 35 & 4.9 & 0.22 \\
\hline 12 & 34 & 34 & 4.9 & 0.21 \\
\hline 13 & 31 & 35 & 5.0 & 0.62 \\
\hline 14 & 30 & 30 & 4.8 & 0.35 \\
\hline 15 & 29 & 32 & 4.9 & 0.43 \\
\hline 16 & 30 & 30 & 4.8 & 0.21 \\
\hline 17 & 28 & 28 & 4.9 & 0.12 \\
\hline 18 & 29 & 35 & 5.0 & 0.5 \\
\hline 19 & 29 & 30 & 5.0 & 0.7 \\
\hline 20 & 32 & 36 & 5.0 & 0.8 \\
\hline
\end{tabular}




\begin{tabular}{|c|c|c|c|c|}
\hline 21 & 33 & 31 & 5.0 & 0.6 \\
\hline 22 & 31 & 33 & 4.9 & 1.1 \\
\hline 23 & 34 & 34 & 4.9 & 1.2 \\
\hline 24 & 30 & 30 & 4.8 & 1.5 \\
\hline 25 & 31 & 33 & 4.8 & 1.7 \\
\hline 26 & 34 & 32 & 4.9 & 2.0 \\
\hline 27 & 31 & 33 & 4.9 & 1.6 \\
\hline 28 & 32 & 31 & 4.8 & 2.1 \\
\hline 29 & 31 & 32 & 4.7 & 1.6 \\
\hline 30 & 28 & 30 & 4.8 & 1.2 \\
\hline
\end{tabular}

\section{RESULTS AND DISCUSSION}

The poultry litter had the highest bioconversion efficiency of $19.58 \%$, this is expected, since the sample had the highest amount of gas production. While, the rice husk had a bioconversion efficiency of $12.08(\%)$. This is as a result of the microorganism for bio-degradation acted more on the poultry litter because it is believed that the feed had been broken down through proper digestion, before excretion by the animal. As such most of the lignin bonds from the food particles that constitute the poultry were broken down for easy digestion.

\section{Conversion efficiency}

Poultry litter and rice husk had bioconversion efficiencies of $12.47(\%)$ and with $4.22(\%)$ respectively, which means that poultry litter had higher conversion efficiency compare to rice husk which indicates that is lower volume of gas production (see table 4.2). This is similar to the result obtained from the research work by Iwuchukwu (2016) where the sample that had the highest gas production rate had higher bioconversion efficiency. It shows that greater fraction of the poultry litter was converted to biogas as compared to the rice husk. Consequently, bioconversion efficiency will also be higher for substrate having the highest number of gas production rate. This variation in gas volume was as a result of their various physical properties. For the rice husk, the waste was not degraded when it was subjected to the digester but the animal litter was already partially bio-degraded through digestion and consequently enabled its speedy reaction.

The variation and low performance of the rice husk as compared to a similar research work done by Ezekoye (2009) where the rice husk was subjected to microbial pretreatment process by the addition of green algae to the rice husk hence, the highperformance rate which means the green algae had a significant effect on the rice husk. According to the researcher, the feedstock that was used in his research had the following features: (1) The sample feedstock did not consist of only rice husk, but a combination of rice husk and algae (2) The rise in the gas production rate was due to the high level of green algae (micro-organism which aids bio-degradation) present (3) A 45 day retention time employed in the work cited, may as well be believed to had encouraged the production of biogas, as compared to a 30 day retention time allocated in this study. 


\section{pH level}

The $\mathrm{pH}$ level relationship between rice husk and the poultry litter. Since poultry litter had a higher gas yield compare to the rice husk, it could be denoted that the $\mathrm{pH}$ level of this feedstock had a significant effect in the production of biogas (see Tab 4.). The optimum $\mathrm{pH}$ interval for mesophilic digestion is between 6.5 and 8.0 and the process is severely inhibited if the $\mathrm{pH}$ value decreases below 6.0 or rises above 8.3 . The solubility of carbon dioxide in water decreases at increasing temperature. The $\mathrm{pH}$ value in thermophilic digesters is therefore higher than in mesophilic type, as dissolved carbon dioxide forms carbonic acid by reaction with water by Omer and Ibrahim (2015).

\section{Effect of Temperature}

The relationship between ambient temperatures, slurry temperature and gas volume produce for poultry litters for a 10 day retention time. It was observed that the ambient temperature had a little variation with that of the slurry temperature. This result corresponds with the those obtained by Opraku et al. (2013), which indicated that when indigestion was carried out using a metallic digester the ambient temperature was a little lower than the slurry temperature. This concession is true because metal digester tends to trap in temperature and the heat generate inside the digester plus that of the surrounding will the greater than the ambient temperature. Also, comparing with a study by Omer and Ahmed (2015) on biogas production from poultry manure, it was observed that their research work was done in a high temperature region of Sudan. The researcher also cited the fact that the poultry birds that produced the manure which was used for their research work were subjected to environmental hazard, where the birds were left to roam about and also there was no proper cleaning of the birds pens which generated harmful bacteria, lice and aerobic bacteria, especially the methanogens, which are sensitive to the acid concentration within the digester and their growth can be inhibited by acidic condition.

The variation in temperature was as a result of the difference in study location. The poultry litters gotten for this research work were free from wood shavings and as such the micro-bacteria from the saw dust in addition to that of the digested waste was minimal. Micro-bacteria tend to act more when there is high temperature for gas to be produced. In conclusion, Sudan has a higher temperature which poses a significant effect with the reaction of the microbial activities in the digester that was used by the researchers. 


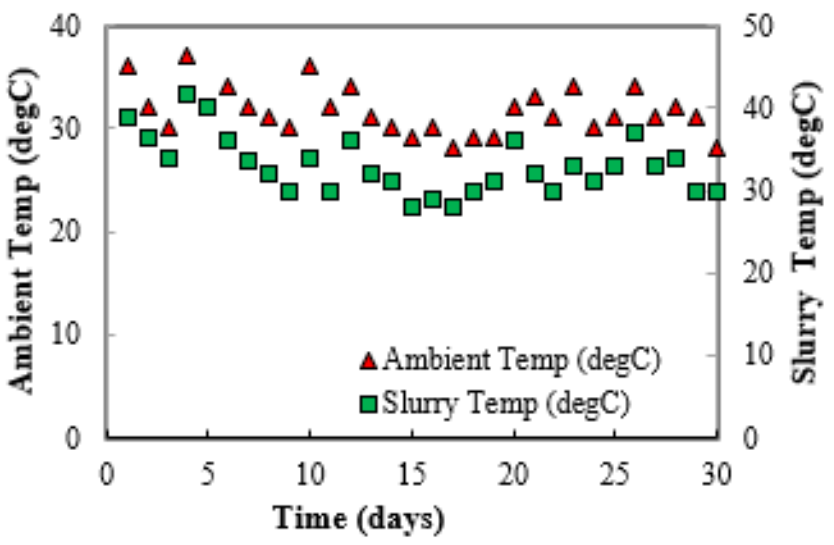

Figure 1. Variation in temperature of the different feedstock

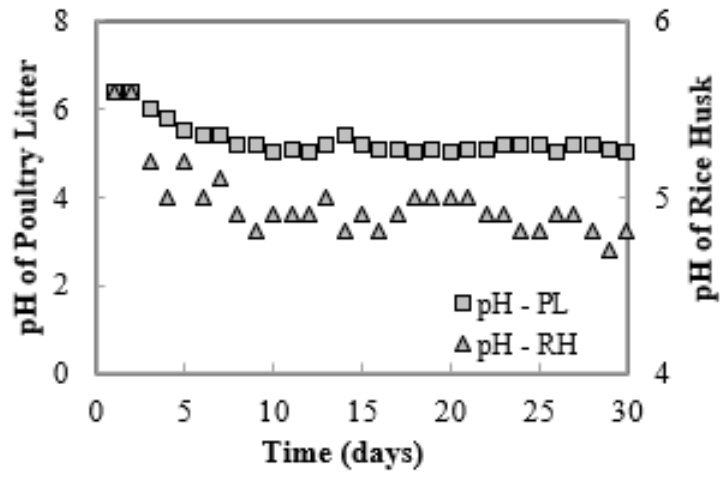

Figure 2. Variation in $\mathrm{pH}$ of the different feedstock

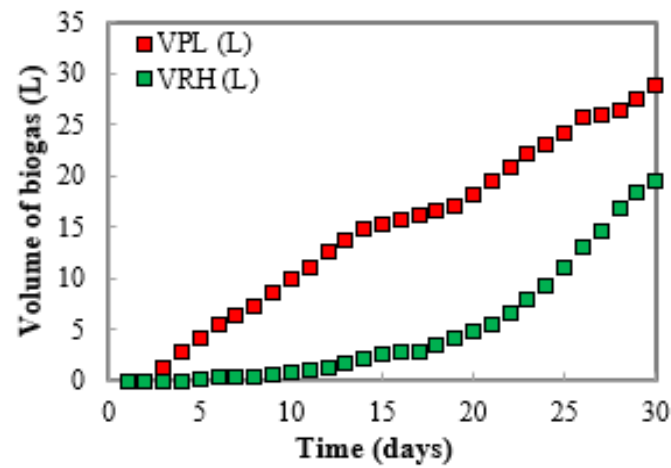

Figure 3. Variation in cumulative biogas volume 


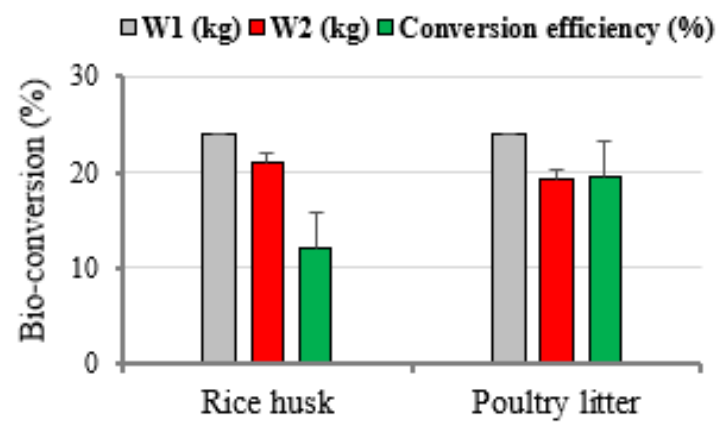

Figure 4. Bio-conversion efficiency

\section{CONCLUSIONS}

In anaerobic digestion, microorganisms digest the organic material producing biogas which can be collected and used as a valuable fuel. The yield of biogas depends on the composition of the waste feedstock and the environment conditions within the reactor. The poultry litter had already undergone some digestion process before it was passed out by the animals which mean their bonds were broken by digestive organism which makes the anaerobic digestion process easily. Similarly, the rice husk had a low gas production rate due to the presence of high lignin properties because rice is a lignin cellulose material. As such, the lignin in the rice husk took a longer period of time to break its bond due to inadequate digestive organisms that could easily digest and break the bonds to produce gas.

\section{REFERENCES}

[1] Adelekan, B.A., Bamgboye, A.I. (2009). Comparison of biogas productivity of cassava peels mixed in selected ratios with major livestock waste. African Journal of Agricultural Research. Vol. 4(7), pp. 571-577.

[2] Ehiem, J.C., Adama, J.C. (2014). Laboratory practical manual for food processing. Agricultural and Bioresources Department, Michael okpara university of agriculture.

[3] Ezekoye, V.A. 2009. The influence of Rice husk on Biomethanation in optimal condition for digestion and domestic use of stored Biogas. The Pacific Journal of Science and Technology, 10(2), pp. 889-897.

[4] Iwuchukwu, B.O. (2016). Digestion of cassava starch effluent blended with cassava Master's Thesis, department of agricultural Engineering, Michael Okpara University of Agriculture, Umudike, Abia State, Nigeria.

[5] Kanokwan, B. (2006). Online monitoring and control of biogas process, Institute of. Environment and Resources, Technical University of Denmark.

[6] Ojikutu, A.O., Osokoya, O.O. (2014). Evaluation of biogas production from food waste. International Journal of Engineering and Science. Vol. 3 (1), pp. 1-7.

[7] Omer, M., Abdul, R., Ahmed, I.A. (2015). University of Khartoum Faculty of Engineering Agricultural and Biological Engineering Department on the topic: Biogas production from poultry manure. 
[8] Opraku, J.R., Helm, P., Grmek, M., Agrinz, G., Prassl, H., Sioulas, K.(2013). Steps specific to cellulose materials in the manuals for Home and farm production of Alcohol fuels, Dioz Production, USA. pp. 32-33.

[9] Oyedepo, O. (2012). Energy and sustainable development in Nigeria: the way forward. Energy, Sustainability and Society 2012. https://doi.org/10.1186/2192-0567-2-15

[10] Petz, W.B. (2008). Biogas potentials and its utilizations. International journal of renewable energy vol. 3 (1).

[11] Sioulas, K., Boukis, I. (2001). Establishment of a network of competent partners for the treatment and energy valorization, by means of Anaerobic Digestion.

\title{
PROCENA MAKSIMALNE PROIZVODNJE BIOGASA IZ RAZLIČITIH SIROVINA: EKSPERIMENTALNA STUDIJA
}

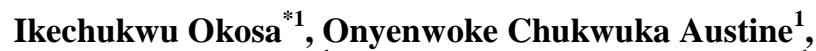 \\ Horsfall Ibiba Taiwo ${ }^{1}$, Umunna Muofunanya Francis ${ }^{1}$. \\ ${ }^{1}$ Department of Agricultural and Bio-Resources Engineering, \\ Michael Okpara University of Agriculture, Umudike, \\ Abia State, Nigeria.
}

Sažetak: Ova studija prikazuje najveći kapacitet proizvodnje biogasa od različitih biomasa, kada se koristi kao početna sirovina biljni i životinjski otpadni materijal. Uporedni eksperiment $u$ anaerobnim uslovima pokazuje da je količina biogasa od živine (28 litara) veći od ljuski pirinča (18 litara) u roku trajanja ciklusa u reaktoru od 30 dana.

Međutim, na prinos biogasa je značajno uticao sastav otpadne sirovine i uslovi životne sredine u reaktoru za gas. Prostirka za živinu već je bila podvrgnuta nekom procesu razgradnje pre nego što je živina (ptice) ostavila svoj deo, što omogućuje da se anaerobni proces lako izvrši. Slično tome, ljuska pirinča ima malu mogućnost proizvodnje gasa zbog prisustva visokih sadržaja celuloze (lignin.

Zbog toga, za optimalnu proizvodnju gasa, otpad treba prethodno predtretirati u oblasti nižih temperatura da bi se posle povećala temperatura razgradnje, jer temperatura digestije u bioreaktoru ima veliki uticaj na proizvodnju biogasa.

Ključne reči: Predviđanje, najveći kapacitet za gas, ljuske pirinča, anaerobno razlaganje.

Prijavljen:

Submitted:

21.10.2019.

Ispravljen:

Revised:

31.01.2020.

Prihvaćen:

Accepted:

02.02.2020

${ }^{* 1}$ Corresponding Author. E-mail.okosain@gmail.com 